\title{
Perforation and mortality after cleansing enema for acute constipation are not rare but are preventable
}

This article was published in the following Dove Press journal:

International Journal of General Medicine

24 April 2013

Number of times this article has been viewed

\section{Galia Niv' \\ Tamar Grinberg² \\ Ram Dickman ${ }^{3}$ \\ Nir Wasserberg ${ }^{4}$ \\ Yaron Nivi,3}

'Risk Management and Quality Assurance, ${ }^{2}$ Emergency Department, ${ }^{3}$ Department of Gastroenterology, ${ }^{4}$ Department of Surgery B, Rabin Medical Center, Beilinson Hospital and Tel Aviv University, Tel Aviv, Israel
Correspondence to: Yaron Niv Rabin Medical Center, 39 Jabotinski Street, Petach Tikva, Israel

Tel +97239377328

Fax +97239210313

Email yniv@clalit.org.il
Objectives: Constipation is a common complaint, frequently treated with cleansing enema. Enemas can be very effective but may cause serious adverse events, such as perforation or metabolic derangement. Our aim was to evaluate the outcome of the use of cleansing enema for acute constipation and to assess adverse events within 30 days of therapy.

Methods: We performed a two-phase study: an initial retrospective and descriptive study in 2010 , followed by a prospective study after intervention, in 2011. According to the results of the first phase we established guidelines for the treatment of constipation in the Emergency Department and then used these in the second phase.

Results: There were 269 and 286 cases of severe constipation in the first and second periods of the study, respectively. In the first study period, only Fleet ${ }^{\mathbb{B}}$ Enema was used, and in the second, this was changed to Easy Go enema (free of sodium phosphate). There was a $19.2 \%$ decrease in the total use of enema, in the second period of the study $(P<0.0001)$. Adverse events and especially, the perforation rate and the 30 -day mortality in patients with constipation decreased significantly in the second phase: $3(1.4 \%)$ versus $0(P=0.0001)$ and $8(3.9 \%)$ versus $2(0.7 \%)$ $(P=0.0001)$, for perforation and death in the first and second period of the study, respectively. Conclusion: Enema for the treatment of acute constipation is not without adverse events, especially in the elderly, and should be applied carefully. Perforation, hyperphosphatemia (after Fleet Enema), and sepsis may cause death in up to $4 \%$ of cases. Guidelines for the treatment of acute constipation and for enema administration are urgently needed.

Keywords: phospho-soda, elderly, dementia, obstipation

\section{Introduction}

Constipation is a common complaint and is associated with significant health care costs. ${ }^{1}$ The elderly are five times more prone to constipation than young people, due to the effect of medication, immobility, and blunted urge to defecate. ${ }^{2}$ Polypharmacy is very frequent among the elderly, and drugs such as pain killers (opiates), antipsychotic, antiparkinson agent, anticholinergic, anxiolytics, calcium, and iron supplements, which are popularly prescribed in the advanced age group, are known to have constipation as a side effect.

Most patients self-medicate to treat constipation, usually with over-the-counter (OTC) drugs, but some need urgent intervention and are referred to the Emergency Department (ED). Many of these patients are demented, have cognitive deficits, or suffer from a psychiatric disorder. The communication between the treating team and these patients may be impaired, and the proper feedback about pain or the side effect of treatments is not optimal. 
Acute constipation requires urgent and comprehensive assessment because a serious medical condition may be the underlying cause. A careful medical history, investigation of medications that can cause constipation, and physical examination including rectal examination are important in all patients with severe constipation, in order to define the type of constipation and direct the physician to the correct diagnosis, treatment, and intervention. Rectal examination can assess sphincter tone and tenderness, and may uncover a palpable mass, fissure, or mucosal prolapse. ${ }^{2,3}$ Even though constipation is a common condition seen in the ED, there has been unequal distribution of knowledge among physicians and nurses regarding this issue, which may explain the wide variance of management and treatment methods for this problem.

Cleansing enema is a popular method for treatment of constipation. The function of enema is dependent on several different mechanisms. By distending the rectum, all enemas stimulate the colon to contract and eliminate stool. Other mechanisms, such as that employing phosphate enemas, directly stimulate the muscles of the colon. Enemas can be very effective but may cause serious adverse events, such as perforation or metabolic derangement. ${ }^{4}$ Hypertonic sodium phosphate enemas may cause severe phosphate nephropathy, especially in the elderly with chronic renal failure or in patients treated with angiotensin-converting enzyme (ACE) inhibitors. ${ }^{5-9}$ Cleansing enema adverse events are rarely reported in the literature but may be life threatening. The most frequent cause of perforation in patients who underwent enema has been reported to be the device tip; other causes are related to localized weakness of the rectal wall, obstruction, or the position of the patient when the enema was performed. ${ }^{10-17}$ We are not aware of any previous study that has looked at the incidence of perforation after enema treatment for acute constipation.

Our aim was to evaluate the outcome of using cleansing enema for severe, acute constipation, in patients referred to the ED of Rabin Medical Center, Beilinson Hospital and to assess the adverse events within 30 days of therapy.

\section{Patients and methods}

A retrospective (first phase) study was conducted between January 1, 2010 and December 31, 2010. We studied all the patients that were referred to the ED on an emergency basis because of severe constipation. We included all patients referred, without exclusion.

Patients' records were reviewed. The data collection included: gender, age, medical history, the results of physical examination, the results of imaging procedures, the type of treatment for constipation, and the outcome assessment, including treatment effectiveness and discharge or hospitalization. We also looked at return visits to the ED within 1 week and 30-day mortality.

A prospective, interventional (second phase) study followed between March 1, 2011 and Feb 29, 2012, using the same methods, after having developed, distributed, and implemented the use of clinical guidelines for the treatment of constipation.

\section{The process of guidelines formation}

An expert committee was convened that included experienced physicians from the departments of Surgery, Gastroenterology, Geriatrics, Nephrology, and Emergency Medicine, and experts from the Risk-Management Unit and Pharmacy. The literature was reviewed, and the results of the retrospective study were discussed. Clinical guidelines for the diagnosis and treatment of acute constipation were written and distributed in the medical center. An implementation program was carried out in the ED, over a period of 2 months.

\section{Statistical evaluation}

The statistical analysis was performed using SPSS for Windows (version 16.0; IBM, Armonk, NY, USA). Categorical data were described proportionally using descriptive statistics. A difference in proportions was tested by Chi-square statistics, with continuity adjustment or Fisher's exact test applied where appropriate. The level of significance adopted was 0.05 .

\section{Results}

\section{Demographic and clinical data}

There were 97,500 and 99,000 visits to the ED at Beilinson Hospital, Rabin Medical Center, in the first and second phases of the study, respectively. The number of patients with constipation was similar, $269(0.27 \%)$ and $286(0.29 \%)$, respectively (Table 1 ). Most of the patients were older than 65 years. There was no statistically significant difference in age and gender between the groups. The length of stay in the ED was significantly shorter in the second period of the study.

\section{Diagnosis and treatment}

The abdominal examination was normal in most of the patients in both study periods, and the physical signs were also similar between the groups. A rectal digital examination was performed in $89.6 \%$ and $99.3 \%$ of the patients in the first and second periods, respectively $(P<0.0001)$ (Table 2$)$. 
Table I Clinical data

\begin{tabular}{|c|c|c|c|}
\hline & Period I & Period 2 & $P$ \\
\hline $\begin{array}{l}\text { Number of total ED visits } \\
\text { per year }\end{array}$ & 97,500 & 99,000 & \\
\hline $\begin{array}{l}\text { Number of patients with } \\
\text { constipation referred to ED }\end{array}$ & $269(0.27 \%)$ & $286(0.29 \%)$ & NS \\
\hline Average age \pm SD (years) & $64.5 \pm 21.8$ & $62.8 \pm 22.7$ & NS \\
\hline \multicolumn{4}{|l|}{ Age } \\
\hline $20-49$ years & $62(23.0 \%)$ & 78 (27.2\%) & NS \\
\hline $50-64$ years & $42(15.6 \%)$ & $5 \mathrm{I}(17.8 \%)$ & NS \\
\hline 65-93 years & 165 (6I.3\%) & I 57 (54.9\%) & NS \\
\hline \multicolumn{4}{|l|}{ Sex } \\
\hline Female & 142 (52.8\%) & 142 (49.6\%) & NS \\
\hline Male & I 27 (47.2\%) & I 44 (50.4\%) & NS \\
\hline \multicolumn{4}{|l|}{ Shifts } \\
\hline Morning (07:00-14:59) & II 8 (43.8\%) & 127 (44.4\%) & NS \\
\hline Evening (15:00-22:59) & II 8 (43.9\%) & I $33(46.5 \%)$ & NS \\
\hline Night (23:00-06:59) & $33(12.3 \%)$ & $26(9.1 \%)$ & NS \\
\hline $\begin{array}{l}\text { Length of stay at ED: } \\
\text { average } \pm \text { SD (hours) }\end{array}$ & $9.1 \pm 5.7$ & $5.5 \pm 4.2$ & $<0.0001$ \\
\hline
\end{tabular}

Abbreviations: ED, Emergency Department, NS, not significant; SD, standard deviation.

Fecal stones were found in 37 patients and a rectal tumor in five. Hemoglobin, white blood cell count, and creatinine levels were similar in both periods. More X-ray studies were performed in the second period. Paralytic ileus was demonstrated in four patients and was suspected in 12 patients.

Cleansing enema was performed in $76.9 \%$ and $57.7 \%$ of the patients in the first and second period of the study, respectively $(P<0.0001)$ (Table 3$)$. In the first period, only Fleet ${ }^{\circledR}$ Enema (phospho-soda) (Fleet Co, Inc, Lynchburg, VA, USA) was used, and in the second period, this was changed to Easy Go enema (Gilco Pharm Ltd, Rishon Le-Zion, Israel) that is free of sodium and phosphate. Age, renal function, blood pressure, or drugs (including ACE inhibitors and $\mathrm{ACE}$ antagonists) were not taken into consideration before treatment with Fleet Enema. A combination therapy of cleansing enema and oral laxative was used in more patients during the first period of study; laxative with no additional enema was used in more patients during the second period.

\section{Follow up and outcome}

Reassessment before discharge from ED was performed in $79.8 \%$ and $99.6 \%$ in the first and second period, respectively $(P<0.0001)$ (Table 4). The perforation rate and the 30-day mortality were significantly higher in the first than in the second period studied. The causes of death are given in Table 5. One patient in the first period of the study died after Fleet Enema because of hyperphosphatemia and
Table 2 Signs, symptoms, and laboratory test results

\begin{tabular}{|c|c|c|c|}
\hline & Period I & Period 2 & $\boldsymbol{P}$ \\
\hline $\mathrm{N}$ & 269 & 286 & \\
\hline \multicolumn{4}{|l|}{ Vital signs (mean $\pm S D$ ) } \\
\hline Pulse & $81 \pm 15$ & $82 \pm 16$ & NS \\
\hline Fever & $36.7 \pm 0.3$ & $36.7 \pm 0.4$ & NS \\
\hline VAS pain score & $4.2 \pm 3.2$ & $3.7 \pm 3.1$ & 0.062 \\
\hline \multicolumn{4}{|l|}{ Blood pressure } \\
\hline Systole, mean \pm SD & $138 \pm 26$ & $138 \pm 24$ & NS \\
\hline Diastole, mean \pm SD & $72 \pm 15$ & $73 \pm 12$ & NS \\
\hline \multicolumn{3}{|l|}{ performed in ED } & NS \\
\hline Abdominal tenderness & $17(6.4 \%)$ & $19(6.6 \%)$ & NS \\
\hline Abdominal distention & $16(6.0 \%)$ & $13(4.5 \%)$ & NS \\
\hline $\begin{array}{l}\text { Suspected incarcerated } \\
\text { hernia }\end{array}$ & I (0.4\%) & 0 & NS \\
\hline Abdominal fullness & $12(4.5 \%)$ & $5(1.7 \%)$ & 0.095 \\
\hline $\begin{array}{l}\text { Normal abdominal } \\
\text { examination }\end{array}$ & $223(84.1 \%)$ & $249(87.1 \%)$ & NS \\
\hline \multicolumn{4}{|l|}{ performed in ED } \\
\hline Refused rectal examination & $6(2.2 \%)$ & $4(1.4 \%)$ & NS \\
\hline Fecal stone & $22(9.1 \%)$ & $15(5.3 \%)$ & NS \\
\hline External hemorrhoids & $3(1.2 \%)$ & $5(1.8 \%)$ & NS \\
\hline Rectal SOL & $4(1.6 \%)$ & I (0.3\%) & NS \\
\hline $\begin{array}{l}\text { Benign prostate } \\
\text { hypertrophy }\end{array}$ & $2(0.8 \%)$ & $3(1.0 \%)$ & NS \\
\hline Normal PR examination & $232(96.3 \%)$ & $258(90.8 \%)$ & NS \\
\hline \multicolumn{4}{|l|}{ Blood tests (mean $\pm S D)$} \\
\hline Hemoglobin & $12.1 \pm 1.4$ & $12.2 \pm 1.6$ & NS \\
\hline WBC & $8596 \pm 3543$ & $8064 \pm 2535$ & \\
\hline Creatinine & $0.9 \pm 0.5$ & $0.9 \pm 0.3$ & \\
\hline Abdominal X-ray & $260(96.6 \%)$ & 285 (99.56\%) & 0.045 \\
\hline \multicolumn{4}{|l|}{ performed in ED } \\
\hline Paralytic ileus & $3(1.1 \%)$ & I (0.3\%) & NS \\
\hline Expansion of bowel loops & $7(2.7 \%)$ & $5(1.7 \%)$ & NS \\
\hline
\end{tabular}

Abbreviations: ED, Emergency Department; NS, not significant; PR, per rectum; SOL, space occupying lesion; VAS, visual analog scale; WBC, white blood cells; SD, standard deviation.

phosphate nephropathy. The rate of return visits was also higher in the first period.

\section{Clinical guidelines}

The guidelines included instructions for diagnosis and the treatment of acute constipation in the ED, the identification of enema risk factors, description of the method of enema administration and follow-up, and recommendation for the specific enema type.

\section{Diagnosis}

When acute constipation is suspected, fecal impaction, rectal tumor, and colonic obstruction should be excluded by a comprehensive abdominal and rectal examination. Drugs and underlying diseases that may cause constipation should be excluded. $\mathrm{X}$-ray study is indicated according to the clinical picture. 
Table 3 Treatments for constipation in the ED

\begin{tabular}{llll}
\hline & Period I & Period 2 & P \\
\hline N & 269 & 286 & \\
Enema administration in ED & $207(76.9 \%)$ & $165(57.7 \%)$ & $<0.000$ I \\
Enema + PO & $133(49.4 \%)$ & $58(20.2 \%)$ & $<0.000$ I \\
Only PO & $46(17.1 \%)$ & $85(29.7 \%)$ & 0.00 I \\
Telebrix ${ }^{\circledR}$ (Guerbet, Villepinte, & $39(14.4 \%)$ & $25(8.7 \%)$ & 0.033 \\
France) & & & \\
Paraffin oil & $104(38.7 \%)$ & $89(31.1 \%)$ & NS \\
Avilac (Amvilabs Inc, Atlanta & III (4I.2\%) & $92(32.1 \%)$ & 0.034 \\
GA, USA) & & & \\
Pain killer & $17(6.3 \%)$ & I6 (5.6\%) & NS \\
No treatment & I3(4.8\%) & $34(11.9 \%)$ & 0.01 I \\
\hline
\end{tabular}

Abbreviations: ED, Emergency Department; NS, not significant; PO, per os.

\section{Treatment}

The use of Fleet Enema (phospho-soda) is forbidden due to the danger of hyperphosphatemia and phosphate nephropathy. Cleansing enema should be performed carefully with another product, and the volume should not exceed $250 \mathrm{~mL}$. Administration of the enema is done with a rectal tube, by experienced personnel. Perforation should always be anticipated and suspected if abdominal pain appears. Cleansing enema is contraindicated in patients with fecal stones, rectal obstruction by tumor or rectal prolapse, active coronary heart disease, and in comatose or noncompliant patients. In addition, enema should be avoided in cancer patients under chemotherapy and in other immunocompromised patients, especially those with severe neutropenia.

\section{Follow up and outcome}

Before patient discharge from the ED, reassessment of the clinical status should be performed and includes physical abdominal examination and measurement of vital signs. Instructions about adverse events or complications that could occur should be discussed. The patient is instructed to return immediately to the ED if rectal bleeding occurs or if abdominal pains appear.

Table 4 Follow-up and outcome

\begin{tabular}{llll}
\hline & Period I & Period 2 & P \\
\hline $\mathrm{N}$ & 269 & 286 & \\
$\begin{array}{l}\text { Reassessment before } \\
\text { discharge from ED (out } \\
\text { of discharged patients) }\end{array}$ & 20 I (79.8\%) & $263(99.6 \%)$ & $<0.000$ I \\
$\begin{array}{l}\text { Revisit ED within I week } \\
\text { for the same reason }\end{array}$ & $37(13.7 \%)$ & $24(8.4 \%)$ & $<0.000$ I \\
$\begin{array}{l}\text { Hospitalization } \\
\text { Rectal perforation }\end{array}$ & $3(1.4 \%)$ & 0 & NS \\
30-day mortality & $8(3.9 \%)$ & $2(0.7 \%)$ & $<0.000$ I \\
\hline
\end{tabular}

Abbreviations: ED, Emergency Department; NS, not significant.

\section{Discussion}

Quality and risk management processes are an essential part of our daily work, in order to improve patient management and safety. We believe that these processes should be based on evidence and good clinical research. In this study, we looked at a very common complaint of constipation, after an anecdotal impression of a high incidence of perforation and mortality.

Constipation is increasingly found in the elderly population and is becoming an important cause of morbidity. ${ }^{1-3}$ The constipation rate in the Western world is 2\%-28\%. ${ }^{3}$ Emergency room visits due to acute constipation in the United States are estimated to be $0.22 \%$ to $0.36 \%$, very similar to our results. ${ }^{18}$ Cleansing enema is a popular practice for the treatment of constipation and is used in many patients referred for this reason to the ED. ${ }^{19}$ Since enema is dispensed as an OTC medication in many countries, many patients arrive at the ED after enema treatment that is not always reported.

In our daily practice we encountered cases of perforation and mortality after cleansing enema but could trace only case reports or small cohort studies in the literature; we could not find any study looking at the incidence of enema complications or adverse events. ${ }^{10-17}$

Two case series from Israel described elderly patients that had perforation after cleansing enema. ${ }^{10,11}$ Paran et $\mathrm{al}^{10}$ described 13 cases of colon perforation occurring after a cleansing enema performed at home or a nursing home, over a 3-year period, in patients with a mean age of 64.3 years, similar to our group. Gayer et $\mathrm{al}^{11}$ described 14 cases of rectosigmoid perforations that were picked up from the CT scan database in a period of 6 years. These patients were older, with an average age of 80 years. Since these articles did not mention the total number of patients that were hospitalized during the studies, the incidence could not be calculated.

Because enema is freely available and largely selfadministered, with no or little inspection, we could not estimate the true rate of adverse events related to its use. Our study is the first to demonstrate the incidence of adverse events and the 30-day mortality rate after cleansing enema performed by a nurse, in acutely constipated patients treated at an ED. We found three cases of rectal perforation and one case of hyperphosphatemia in the first period of the study compared with no cases in the second period, and this may be due to the new comprehensive guidelines that were established and implemented by the physicians and nurses. The main difference in clinical behavior between the periods of the study was the preference for oral laxatives over 
Table 5 Characteristics of patients who died

\begin{tabular}{|c|c|c|c|c|c|c|c|c|}
\hline Sex & Age & $\begin{array}{l}\text { PR } \\
\text { findings }\end{array}$ & $\begin{array}{l}\text { Abdominal } \\
\text { examination } \\
\text { findings }\end{array}$ & $\begin{array}{l}\text { X-ray } \\
\text { findings }\end{array}$ & Treatment & $\begin{array}{l}\text { Reassessment } \\
\text { after treatment }\end{array}$ & Death & Comments \\
\hline \multicolumn{9}{|c|}{ Period I } \\
\hline Female & 86 & Normal & Normal & Not done & $\begin{array}{l}\text { Fleet }^{\circledR} \text { enema } \\
\text { (Fleet Co, Inc, } \\
\text { Lynchburg, VA, USA) }\end{array}$ & No & Within I day & Hyperphosphatemia \\
\hline Female & 52 & Fecal stones & Normal & Not done & $\begin{array}{l}\text { Fleet enema, Avilac } \\
\text { (Amvilabs Inc, Atlanta, } \\
\text { GA, USA), paraffin }\end{array}$ & Yes & Within I day & $\begin{array}{l}\text { Impaired patient, lost for } \\
\text { follow-up }\end{array}$ \\
\hline Female & 76 & Fecal stones & Normal & Not done & $\begin{array}{l}\text { Fleet enema, } \\
\text { Telebrix }^{\circledR} \text { (Guerbet, } \\
\text { Villepinte, France) }\end{array}$ & Yes & Within 5 days & Lost for follow-up \\
\hline Female & 86 & Normal & Inguinal hernia & Normal & Fleet enema, Avilac & Yes & Within 6 days & Lost for follow-up \\
\hline Female & 93 & Normal & Normal & Normal & Fleet enema, Avilac & Perforation & Within II days & Immediate operation \\
\hline Male & 86 & Not done & Normal & Normal & Fleet enema & No & Within 21 days & $\begin{array}{l}\text { Perforation was found } \\
\text { at the return visit } 3 \text { days } \\
\text { after enema administration }\end{array}$ \\
\hline Male & 55 & Normal & Inflation & Normal & Fleet enema & No & Within 3 weeks & $\begin{array}{l}\text { Enema performed under } \\
\text { severe neutropenia. } \\
\text { Hospitalization for sepsis } \\
4 \text { days later }\end{array}$ \\
\hline Male & 81 & Normal & Normal & Normal & Fleet enema & Yes & Within I month & Pneumonia \\
\hline Male & 72 & Normal & Tenderness & Not done & Fleet enema & No & Within 3 days & $\begin{array}{l}\text { Perforation } 9 \text { hours after } \\
\text { enema that was performed } \\
\text { in another hospital }\end{array}$ \\
\hline \multicolumn{9}{|c|}{ Period 2} \\
\hline Male & 64 & Normal & Tenderness & Normal & No enema & Yes & Within 3 weeks & End-stage cancer \\
\hline Female & 89 & Normal & Normal & Normal & No enema & Yes & Within I month & End-stage cancer \\
\hline
\end{tabular}

Abbreviation: PR, per rectum.

enemas and the careful reassessment of the patient prior to discharge, shown in the second period. Of course, we could not separate the role of the enema in causing perforation and mortality from the other potential factors. In addition, we recommended using a flexible rectal tube to overcome the danger of perforation due to the rigid tip of the enema.

Patients presenting to the ED can be demented, have cognitive deficits, or have psychiatric disorder, and in these situations, communication is not optimal and sometimes lacking. Thus, invasive procedures requiring understanding and consent should be avoided as much as possible. Moreover these patients can have a high incidence of fecal impaction and fecal stones, which may cause stercoral ulcers and perforation. ${ }^{16}$ Perforation, if this occurs, is on a background of a colon full of fecal material and carries a very high risk of peritoneal spilling and peritonitis. The issue of phosphate enema is also important, and we believe this medication should not be used. There are many descriptions of phosphate nephropathy, in addition to the case that occurred in our study.

The limitations of our study arise from being a single center experience and from the lack of clinical information (medical history and medications) about the patients studied.
In the ED, the medical history taken is not as comprehensive as for hospitalized patients.

In conclusion, enema for the treatment of acute constipation is not without adverse events, especially in the elderly, and should be applied carefully. Perforation, hyperphosphatemia (after Fleet Enema), and sepsis may occur, causing death in up to $4 \%$ of cases. National guidelines for the treatment of acute constipation and for enema administration are urgently needed.

\section{Author contributions}

Galia Niv contributed to the study conceptualization, data collection, data analysis, preparation of the manuscript, and was responsible for study supervision; Tamar Grinberg participated in data collection; Nir Waserberg and Ram Dickman participated in study conceptualization, patient management; Yaron Niv contributed to the study conceptualization, data collection, data analysis, preparation of the manuscript, and was responsible for study supervision.

\section{Disclosure}

The authors report no conflicts of interest in this work. 


\section{References}

1. Martin BC, Barghout V, Cerulli A. Davies C. Direct medical costs of constipation in the United States. Manag Care Interface. 2006;19(12):43-49.

2. Bouras EP, Tangalos EG. Chronic constipation in the elderly. Gastroenterol Clin North Am. 2009;38(3):463-480.

3. Locke GR 3rd, Pemberton JH, Phillips SF. AGA technical review on constipation. American Gastroenterological Association. Gastroenterology. 2000;119(6):1766-1778.

4. Ramakrishnan K, Scheid DC. Enemas: A "Purge" Atory. Internet J Gastroenterol. 2004;3(1).

5. Davies C. The use of phosphate enemas in the treatment of constipation. Nurs Times. 2004;100(18):32-35.

6. Ori Y, Rozen-Zvi B, Chagnac A, et al. Fatalities and severe metabolic disorders associated with the use of sodium phosphate enemas: a single center's experience. Arch Intern Med. 2012;172(3):263-265.

7. Bobba RK, Arsura EL. Septic shock in an elderly patient on dialysis: enema-induced rectal injury confusing the clinical picture. JAm Geriatr Soc. 2004;52(12):2144.

8. Knobel B, Petchenko P. Hyperphosphatemic hypocalcemic coma caused by hypertonic sodium phosphate (fleet) enema intoxication. J Clin Gastroenterol. 1996;23(3):217-219.

9. Korzets A, Dicker D, Chaimoff C, Zevin D. Life-threatening hyperphosphatemia and hypocalcemic tetany following the use of fleet enemas. J Am Geriatr Soc. 1992;40(6):620-621.

10. Paran H, Butnaru G, Neufeld D, Magen A, Freund U. Enema-induced perforation of the rectum in chronically constipated patients. Dis Colon Rectum. 1999;42(12):1609-1612.
11. Gayer G, Zissin R, Apter S, Oscadchy A, Hertz M. Perforations of the rectosigmoid colon induced by cleansing enema: CT findings in 14 patients. Abdom Imaging. 2002;27(4):453-457.

12. Tanswell IJ, Irfan K, Kossakowski T, Townson G. Rectal perforation in ulcerative colitis: complication of an enema tip. Gastrointest Endosc. 2009;69(2):344.

13. Saltzstein RJ, Quebbeman E, Melvin JL. Anorectal injuries incident to enema administration. A recurring avoidable problem. Am J Phys Med Rehabil. 1988;67(4):186-188.

14. Nakamura H, Iyoda M, Sato K, Kitazawa K. Retrograde hydrostatic irrigation enema-induced perforation of the sigmoid colon in a chronic renal failure patient before colonoscopy. J Intern Med Res. 2005;33(6):707-710.

15. Blatt LJ. Injury of the rectum by tip of disposable enema. Report of a case. Arch Surg. 1960;80:442-444.

16. Craft L, Prahlow JA. From fecal impaction to colon perforation. Am J Nurse. 2011;111(8):38-43.

17. Mori H, Kobara H, Fujihara S, et al. Rectal perforations and fistulae secondary to a glycerin enema: closure by over-the-scope-clip. World J Gastroenterol. 2012;18(24):3177-3180.

18. Shah ND, Chitkara DK, Locke GR, Meek PD, TalleyNJ. Ambulatory care for constipation in the United States, 1993-2004. Am J Gastroenterol. 2008;103(7):1746-1753.

19. Sun SX, Dibonaventura M, Purayidathil FW, Wagner JS, Dabbous O, Mody R. Impact of chronic constipation on health-related quality of life, work productivity, and healthcare resource use: an analysis of the National Health and Wellness Survey. Dig Dis Sci. 2011;56(9):2688-2695.

\section{Publish your work in this journal}

The International Journal of General Medicine is an international, peer-reviewed open-access journal that focuses on general and internal medicine, pathogenesis, epidemiology, diagnosis, monitoring and treatment protocols. The journal is characterized by the rapid reporting of reviews, original research and clinical studies across all disease areas.

\section{Dovepress}

A key focus is the elucidation of disease processes and management protocols resulting in improved outcomes for the patient.The manuscript management system is completely online and includes a very quick and fair peer-review system. Visit http://www.dovepress.com/ testimonials.php to read real quotes from published authors. 